\title{
INCIDENCE DYNAMIC OF POD ROT DISEASE OF COCOA CLONES IN LAMPUNG, INDONESIA
}

\author{
Rusdi Evizal ${ }^{1}$, Sugiatno $^{2}$, Ivayani ${ }^{3}$, Hidayat Pujisiswanto ${ }^{2}$, \\ Lestari Wibowo ${ }^{3}$, \& Fembriarti Erry Prasmatiwi ${ }^{4}$ \\ ${ }^{1}$ Department of Agrotechnology, ${ }^{2}$ Department of Agronomy and Horticulture \\ ${ }^{3}$ Department of Plant Protection, ${ }^{4}$ Department of Agribusiness \\ Faculty of Agriculture, University of Lampung, Indonesia \\ J1. Prof. Dr. Sumantri Brodjonegoro No.1 Bandar Lampung 35145 \\ Email: rusdi.evizal@fp.unila.ac.id
}

\begin{abstract}
Incidence dynamic of pod rot disease of cocoa clones in Lampung, Indonesia. The declining of production and productivity of cocoa in Indonesia might due to pests and diseases attacks and planting unselected clones. Dynamic of pod rot incidence was important to plan pest controlling. To study dynamic incidence of some cocoa clones, a research was conducting in Pesawaran District, a centre of cocoa production in Lampung. A farmer cocoa plot under agro-forestry system was selected which had been upgrading in 2014 by pruning and side-grafting with national clones including Sul 1, MCC 1, MCC 2, ICCRI 7 and selected local clone named T1, T2, and T3. The results showed that pod rot incidence occurred along the year of observation. For immature pod, pod rot incidence was dynamic and varied among observerd months and clones. There was high pod rot incidence every months for particular clone. National clone Sul1 and local clone T3 exhibited more tolerant to pod rot disease than other clones. Clones Sul1 and T3 also produced more pod than others. High incidence of pod rot occurred on fruit stage of cherelle (incidence $38.7 \%$ ) and small pod (incidence $18.8 \%$ ) that well known as cherelle wilt symptom.
\end{abstract}

Key words: cherelle, local clones, cocoa, incidence, pod rot, tolerant

\section{ABSTRAK}

Keterjadian penyakit busuk buah kakao pada klon kakao di Lampung, Indonesia. Penurunan produksi dan produktivitas kakao Indonesia antara lain disebabkan oleh serangan hama dan penyakit serta penanaman bibit nonklonal asalan. Dinamika keterjadian penyakit busuk buah penting untuk perencanaan pengendalian. Untuk mempelajari dinamika keterjadian busuk buah pada beberapa klon kakao, dilakukan observasi pada plot kebun kakao di Kabupaten Pesawaran yang merupakan sentra produksi kakao di Lampung. Plot tersebut merupakan sistem kakao agroforest yang telah direhabilitasi pada tahun 2014 dengan cara dipangkas dan disambung samping menggunakan klon nasional Sul 1, MCC 1, MCC 2, ICCRI 7 dan klon lokal T1, T2, dan T3. Hasilnya menunjukkan bahwa keterjadian busuk buah ditemukan sepanjang tahun. Pada buah yang belum matang, keterjadian busuk buah bersifat dinamis bergantung dari bulan pengamatan dan klon dimana setiap bulan selalu terdapat keterjadian busuk buah yang tinggi pada klon tertentu. Klon nasional Sull dan klon lokal T3 menunjukkan lebih toleran terhadap penyakit busuk buah dan menghasilkan lebih banyak buah daripada klon lainnya. Keterjadian busuk buah yang tinggi ditemukan pada fase buah sangat kecil (cherelle) dengan keterjadian 38,7\% dan buah kecil dengan keterjadian $18,8 \%$ yang dikenal dengan gejala Cherelle wilt.

Kata kunci: busuk buah, cherelle, kakao, keterjadian, klon lokal, toleran

\section{INTRODUCTION}

In 2010, Indonesia is achieving as the third world biggest producer of cocoa after Ivory Coast and Ghana. However, production has been decreasing since 2010 from 837,918 to 593,331 metric tons of cocoa bean in 2015 although plantation area is increasing from 1,650,356 to 1,709,284 ha (Directorate General of Estate Crops, 2016). The declining of production and productivity might due to pests and diseases attacks, in particular of cocoa pod borer (CPB), Phytophthora pod rot (PPR) and vascular steak dieback (VSD), unselected planting materials (McMahon et al., 2015; Evizal et al., 2016), poor pruning and sanitation of cocoa field, and yet many cocoa trees were more than 20 years old that need to be replanted or rejuvenated especially in Lampung Province (Evizal et al., 2018; Rubiyo \& Siswanto, 2012). Rehabilitation was a national program (named The national movement to increase cocoa productivity and quality) by upgrading non-productive 
cocoa field through rejuvenating and side-grafting using superior clones (Danial et al., 2015), especially clones with good adaptation to local agro-climate condition and agro-ecosystem (Saidah et al., 2015).

National clones that performed high yield and resistance to pests and diseases has been recommended as clonal plant material such as ICCRI 7 and Sul 1. Sul 1 was superior clone due to high yield and tolerance to VSD while ICCRI 7 has high yield and quality and tolerance to CPB (Anita-Sari \& Susilo, 2013; Anita-Sari \& Susilo, 2015). Nevertheless Susilo et al. (2015) recommended selected local clones such as MCC 1 and MCC 2 that performed more stable and higher yield than Sul 1. Yet MCC 01 was moderate resistance to $\mathrm{CPB}$ and VSD and resistance to PPR, while MCC 02 was resistance to CPB, VSD and PPR.

Phytophthora is able to infect the pods at all stages of development that causing black pod rot and cherelle wilt disease (Guest, 2007; McMahon \& Purwantara, 2004). Black pod rot of cocoa may be caused by Phytophtora palmivora (Vanegtern et al., 2015; Iwaro et al., 2006) and Phytophthora megakarya (Akrofi, 2015; Deberdt et al., 2008). Young cocoa pods, known as cherelles, are commonly lost to physiological thinning known as cherelle wilt but also susceptible to fungi (Melnick et al., 2013).

According to Rubiyo \& Amaria (2013), pod rot disease is the major cocoa disease in Indonesia that may reduce the production of cocoa up to $44 \%$. Moreover, pod rot disease causes more production losses globally than any other disease of cocoa. P. palmivora has several hundred recorded hosts and is of universal importance in cocoa, causing global yield losses up to 20 to $30 \%$ and tree deaths of up to $10 \%$ annually (Guests, 2007). Utilizing plant material of clones which are tolerant or resistant to pests and diseases is an important mean of integrated pest management beside others cultural practices, biological control, pheromones, monitoring and applying pesticide (Adu-Acheampong et al., 2015; Acebo-Guerrero et al., 2012).

Scavina clones (including Sca 6 and Sca 12) have been used as the major source of disease resistance in cocoa breeding, including for black pod rot (Phytophthora spp.) and frosty pod. However the main founder germplasm groups in Indonesia especially in the Sulawesi farmer selections were three traditional varieties (Trinitario, Amelonado and Criollo) and two wild cocoa germplasm groups (Nanay and Parinari), while wild cocoa from Perunian Amazon (Sca) had little contribution (Dinarti et al., 2015). Amelonado (lower Amazon Forastero) is ancient variety with "melon shaped". Trinitario, is a complex hybrids of Criollo and Forastero, derived from at least three original introduction events (Zhang \& Mutilal, 2016). Cluster Nanay (Na), sub-cluster Parinari (PA, cluster Maranon), and sub-cluster Scavina (cluster Contanama) are cocoa of Upper Amazon Forastero according to genetic clustering by Motamayor et al. (2008).

Iwaro et al. (2006) reported that PA clones had largest percentage of persistence (resistant-moderately) among 11 accession groups. Higher proportions of resistant and moderately resistant genotypes were found in the wild accessions than in the cultivated varieties. The Forastero group, consisting of many wild accessions, was found to contain more resistant and moderately resistant genotypes than Trinitario. However, Rubiyo \& Amaria (2013) stated that beside Sca 12 and Sca 6 (Upper Amazon Forastero), clones ICS 6, DRC 15, DRC 16, ICCRI 3, ICCRI 4 (Trinitario) were found as clones with better resistance than other clones to be used for breeding and planting material.

Lampung province is the $7^{\text {th }}$ largest producers of cocoa in Indonesia, with 70,564 ha of cocoa plantation, where Lampung Selatan, Tanggamus and Pesawaran District are the main producer area (Directorate General of Estate Crops, 2016). Farmers have adopted elite national clone such as Sul 1, MCC 1, MCC 2, ICCRI 7 and local clones selected by farmers from hybrids of Forastero or Trinitario. This research aimed to study dynamic incidence of pod rot of national and local cocoa clones in Lampung.

\section{MATERIALS AND METHODS}

Research Site. The research was conducted at farmer cocoa plot under agro-forestry system in Way Ratai Subdistrict, with months of dry season during June to September (Figure 1).

The shade trees were cash crops such as banana, coconut, and durio. Cocoa trees were upgrading in 2014 by pruning and side-grafting Pesawaran District of Lampung Province. Rainfall in the region was about $2050.1 \mathrm{~mm}$ per year with 4 with national clones including Sul 1, MCC 1, MCC 2, ICCRI 7 and selected local clone named T1, T2, and T3. The trial plot was managed by normal farm practice with hand weeding 4 times a year, pruning 3 times a year, fertilizing twice a year (NPK $250 \mathrm{~g}$ per tree), no pesticide was applied, and mulch from falling leaf and weed was collected and arranged between rows.

For each clones we observed 6 trees sampled randomly in the multi-clonal population. We counted number of healthy and rotten pods (with minimum 0.25 $\mathrm{cm}^{2}$ of black rot) in the stage of fruit development 
according to Niemenak et al. (2010). The fruit stages were cherelle (BBHC 70-74), small pods (BBHC 7576), big pods (BBHC 77-80), and ripe pods (BBHC 8189). The symptom of black pod rot disease was observed according to Guest (2007). Diseased pods were not removed from trees after observations. Data were collected in 2016-2017 and analyzed descriptively. Incidence of pod rot was obtained as percentage of rotten pod per total pod for particular pod stage (Efombagn $e t$ al., 2004). Percentage of pod rot between clones was compared by descriptive-quantitative analysis.

\section{RESULTS AND DISCUSSION}

In average of the incidence at all pod stage, the result showed that pod rot incidence occurred along the year (Table 1). There was no significant difference of pod rot incidence among the months and the clones due to high standard deviation. The highest incidence (20.8\%) was found in August when dry season occurred and then was continue high during wet season (Figure 1). Among the clones, MCC 1 had the highest incidence (22.1\%). MCC 1 had been reported (McMahon et al., 2015) as susceptible to pod rot diseases. Clone Sul 1, MCC 2, ICCRI 7, and T3 had lower incidence (8-13\%). MCC 2 was resistant to pod rot diseases as reported by McMahon et al. (2015) and Susilo et al. (2015).

The result showed that pod rot incidence varied between clones. Pod rot incidence commonly higher for cherelle and small pod and then it might be decreasing following pod maturity (Figure 2). This indicated that pods at early of development (until age 2-3 months) were susceptible to pod rot as reported by Efombagn et al. (2004). McMahon et al. (2015) reported that susceptible clones such as MCC had rot incidence on mature and immature pod. Hoopen et al. (2012) stated that several factors are involved in pod rot susceptibility, such as the fruiting cycle, fruit size, age, position on the tree and cocoa genotype. Pod growth model was of a sigmoid form with increasing growth occurred in first three months, well known as thinning stage of the cocoa pod. Figure 2 showed that national clone Sul 1 had lowest



Figure 1. Average of rainfall year 2002-2011 in Pesawaran District Source: BMKG Masgar, Pesawaran, Lampung

Table 1. Percentage of pod rot incidence at all pod stage (cherelle up to ripe pod) in 2016-1017

\begin{tabular}{lcccccc}
\hline Clone & August & October & December & February & April & Average \\
\hline T1 & $19.6 \pm 32.5$ & $23.7 \pm 43.3$ & $12.0 \pm 21.6$ & $27.0 \pm 43.5$ & $6.5 \pm 11.1$ & $17.7 \pm 8.4$ \\
T2 & $25.3 \pm 27.3$ & $26.1 \pm 21.3$ & $12.5 \pm 21.2$ & $21.1 \pm 32.1$ & $4.0 \pm 8.9$ & $17.8 \pm 9.4$ \\
T3 & $16.6 \pm 37.2$ & $19.0 \pm 4.5$ & $8.9 \pm 15.0$ & $5.1 \pm 11.5$ & $14.3 \pm 18.5$ & $12.8 \pm 5.7$ \\
MCC1 & $32.3 \pm 41.6$ & $20.0 \pm 44.7$ & $17.7 \pm 25.5$ & $31.3 \pm 26.5$ & $9.3 \pm 18.9$ & $22.1 \pm 9.7$ \\
MCC2 & $21.6 \pm 29.8$ & $10.0 \pm 13.6$ & $20.0 \pm 44.7$ & $2.9 \pm 6.4$ & $8.6 \pm 7.8$ & $12.6 \pm 7.9$ \\
ICCRI7 & $16.6 \pm 33.3$ & $23.3 \pm 25.2$ & $8.8 \pm 14.4$ & $5.8 \pm 13.1$ & $2.8 \pm 3.9$ & $11.5 \pm 8.4$ \\
Sul1 & $13.3 \pm 27.5$ & $10.0 \pm 22.3$ & $6.6 \pm 9.1$ & $3.3 \pm 5.5$ & $6.0 \pm 9.1$ & $7.8 \pm 3.8$ \\
\hline Average & $20.8 \pm 32.7$ & $18.8 \pm 30.4$ & $12.4 \pm 21.6$ & $13.8 \pm 19.8$ & $7.4 \pm 8.4$ & $14.6 \pm 5.3$ \\
\hline
\end{tabular}


rot incidence for pod at small until ripe stage. However no clone was resistant to pod rot disease. For most of clones such as T1, T2, MCC1, MCC2 and ICCRI 7 pod rot incidence occurred in all stage of pod development.

Figure 3 showed that dynamic of pod rot incidence of immature pod (cherelle wilt was excluded) varied among months and clones. High incidence was commonly found in wet season October-February (Figure 1). However there was high pod rot incidence (incidence $>$ $10 \%$ ) every months for particular clone. For susceptible clones such as T1, T2, MCC1, and ICCRI 7 pod rot incidence was high in 2-4 months of observation. Clone $\mathrm{T} 2$ came through a high incidence along the year as well as $\mathrm{MCC} 1$ although in October no incidence was recorded because no pod was found (Table 2) indicating that all pod dropped caused by pod rot during August. MCC1 was susceptible to pod rot that high pod rot incidence commonly occurred on fruiting season (February-July) could lead to high yield loss (McMahon et al., 2015). In February when many pods were available on the trees, pod rot incidence covered 5-30\% of the pod which clone
MCC2 and Sul1 were the least (incidence around 5\%). Clone MCC2 had high incidence in December when only few pods existed on the trees (Table 2). Pod rot incidence in April was important because it was the peak of harvesting. Fortunately, pod rot incidence decreased during April for most clones except clone T3 and MCC2. Clone Sul1 had pod rot incidence less than $5 \%$ along the year could be considered as tolerant or moderately resistant clone as stated by Iwaro et al. (2006).

Figure 4 showed a dynamic of pod rot incident based on fruit development stage. High incidence of pod rot occurred on fruit stage of cherelle $(38.7 \%)$ and small pod (18.8\%). However, in December cherelle wilt was less than $10 \%$. Rot incidence of small pods was high along the year (10.6-31.7\%). Starting from August, medium and big pods suffered the highest pod rot incidence (16-17\%) in December during the wet season then the incidence was decreasing. Incidence $3.2 \%$ was found on ripe pods during period of August-April.

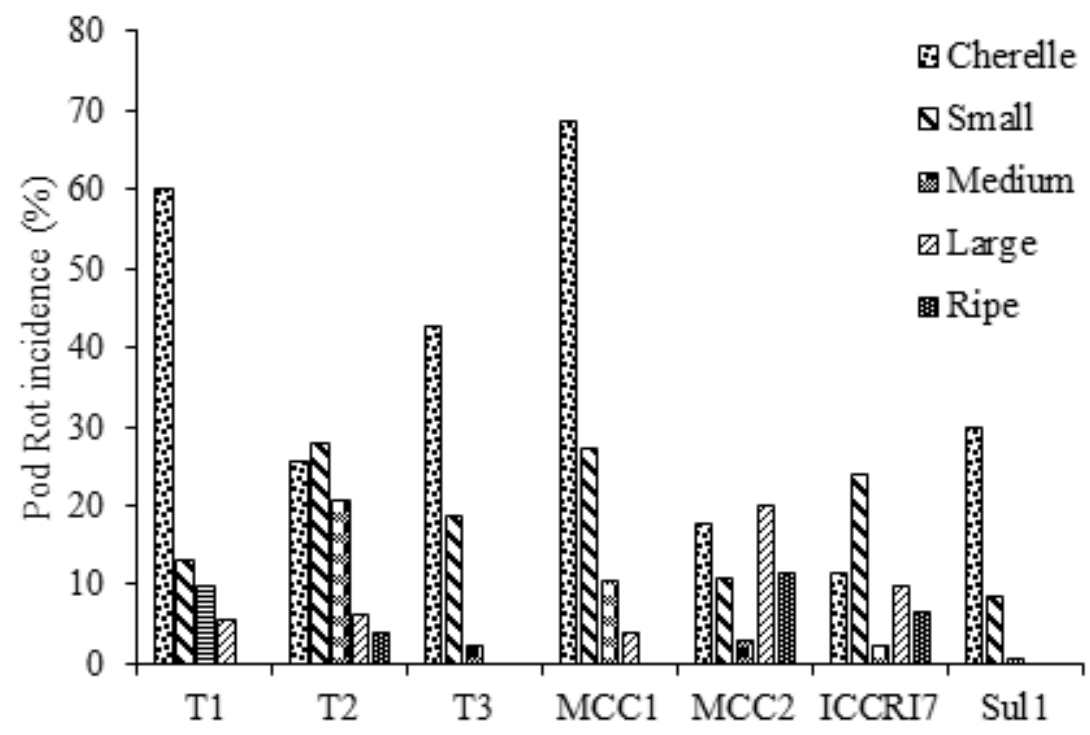

Figure 2. Pod rot incidence of cocoa clones at different stage of pod development.

Tabel 2. Dynamic of immature pod of different cocoa clones in Lampung (2016-2017)

\begin{tabular}{lcccccc}
\hline \multicolumn{1}{c}{ Clone } & August & October & December & February & April & Average \\
\hline T1 & $5.16 \pm 2.63$ & $2.3 \pm 2.1$ & $5.0 \pm 4.1$ & $17.5 \pm 10.3$ & $15.4 \pm 6.6$ & $9.1 \pm 6.8$ \\
T2 & $10.4 \pm 4.72$ & $3.2 \pm 3.7$ & $3.4 \pm 4.2$ & $18.4 \pm 22.2$ & $6.2 \pm 8.9$ & $8.3 \pm 6.3$ \\
T3 & $10.0 \pm 6.9$ & $3.3 \pm 3.0$ & $12.3 \pm 8.0$ & $35.3 \pm 5.0$ & $22.2 \pm 6.5$ & $16.6 \pm 12.4$ \\
MCC1 & $8.0 \pm 4.3$ & $0.0 \pm 0.0$ & $3.7 \pm 2.1$ & $23.6 \pm 3.2$ & $13.0 \pm 3.7$ & $9.7 \pm 9.2$ \\
MCC2 & $3.0 \pm 0$ & $1.0 \pm 0.0$ & $2.5 \pm 0.7$ & $20.2 \pm 14.2$ & $10.0 \pm 7.5$ & $7.3 \pm 8.0$ \\
ICCRI7 & $5.0 \pm 2.4$ & $2.2 \pm 1.5$ & $4.2 \pm 3.6$ & $27.2 \pm 11.5$ & $15.1 \pm 6.8$ & $10.8 \pm 10.5$ \\
Sul1 & $10.4 \pm 9.1$ & $2.0 \pm 2.9$ & $3.8 \pm 5.0$ & $28.4 \pm 19.8$ & $20.7 \pm 13.4$ & $13.1 \pm 12.3$ \\
\hline Average & $7.4 \pm 3.0$ & $2.0 \pm 1.2$ & $4.9 \pm 3.3$ & $24.4 \pm 6.4$ & $14.6 \pm 5.6$ & $10.7 \pm 8.9$ \\
\hline
\end{tabular}


Mostly each stage of fruit development existed every month of observation indicating that fruit cycles were over-lapping along the year. In August we observed high incidence of pod rot of cherelle and small pod that commonly known as cherelle wilt of cocoa. As symptom of small fruit thinning, cherelle wilt or new pod abortion was related to the number new pod which was peak on July-August (Adjaloo et al., 2012).

Table 2 figured dynamic of the total number of immature pod (small, medium and big pod). Number of pod was low during August-December and significantly higher in February then decreasing in April. This pattern was different from those in West Java where number of pod was similar between semester I (January-June) and semester II (August-December) as reported by (Prawoto, 2014). In fact, cocoa pods existed along the year as well as pod rot disease. Pod rot incidence was driven by wet season (Figure 3-4) as reported by McMahon et al. (2015), pod development stage and fruiting season.

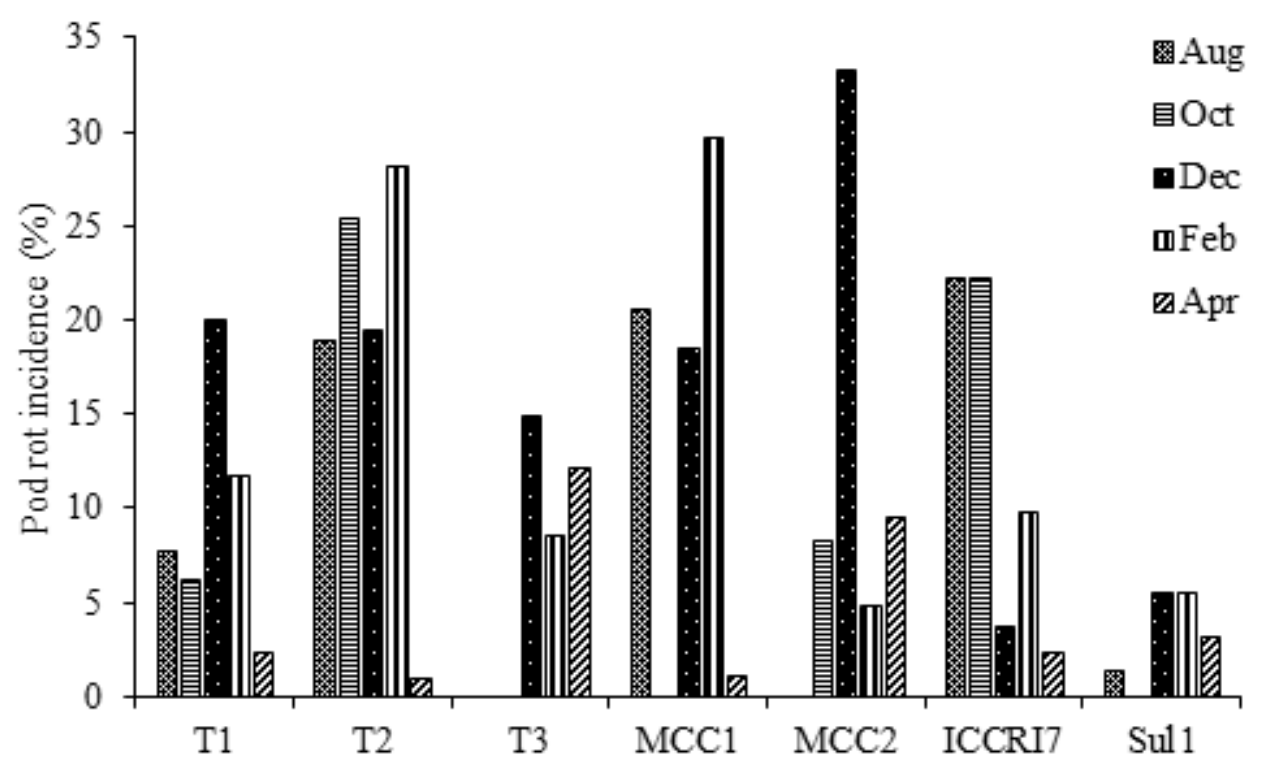

Figure 3. Dynamic of pod rot incidence for immature pod (small, medium, large).

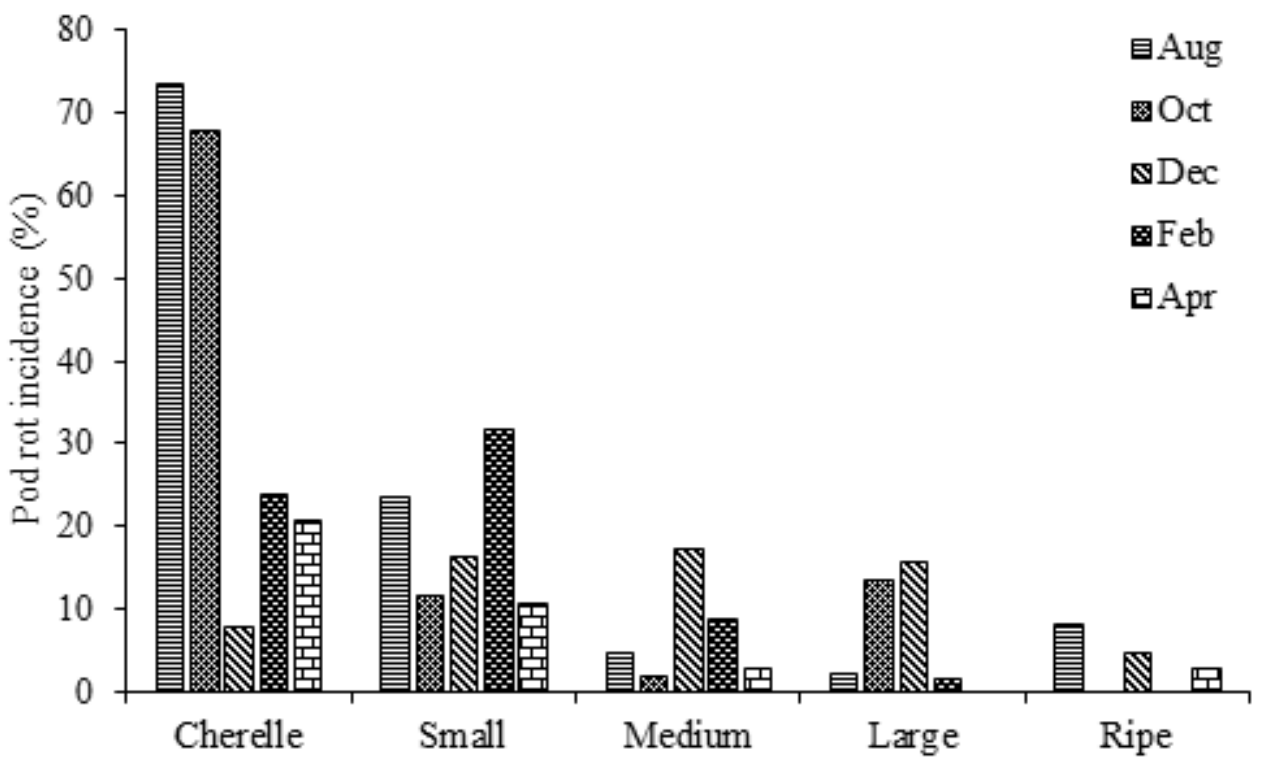

Figure 4. Dynamic of pod rot incidence based on fruit development stage. 
In average there was no significant difference of yield among the clones. However clone T1, T2, MCC1, MCC2, ICCRI 7 produced lower number of pod per month than those of local clone T3 and Sull. Local clone T3 and national clone Sul1 exhibited high pod number during February-April. Therefore based on number of fruit, local clone $\mathrm{T} 3$ was potential clone to be developed especially in Lampung. Moreover local clone T3 was tolerant to pod rot disease with incidence $8-15 \%$ for immature pod (Figure 2). Selecting cocoa trees from farm population might found resistant clones as reported by Thevenin et al. (2012).

\section{CONCLUSION}

From the results we concluded that pod rot incidence occurred along the year of observation. The highest rot incidence of all pod phase was found in August and then was decreasing. For immature pod, pod rot incidence was dynamic and varied among months and clones. There was high pod rot incidence (incidence $>10 \%$ ) every months for particular clone. National clone Sull and local clone T3 exhibited more tolerant to pod rot disease than other clones. Yet, clones Sull and T3 also produced more pod than others. High incidence of pod rot occurred on fruit stage of cherelle (incidence $38.7 \%$ ) and small pod (incidence 18.8\%) that well known as cherelle wilt symptom.

\section{ACKNOWLEDGMENTS}

We thank LPPM of Lampung University for funding this research through scheme of "Superior Research Grant" in 2017.

\section{REFERENCES}

Acebo-Guerrero Y, Hernandez-Rodriguez A, HeydrichPerez M, El Jaziri M, \& Hernandez-Lauzardo AN. 2012. Management of black pod rot in cacao (Theobroma cacao L.): a review. Fruits. 67(1): 41-48.

Adjaloo MK, Oduro W, \& Banful BK. 2012. Floral phenology of upper amazon cocoa trees: implications for reproduction and productivity of cacao. ISRN Agronomy: 8.

Adu-Acheampong R, Sarfo JE, Appiah EF, Nkansah A, Awudzi G, Obeng E, Tagbor P, \& Sem R. 2015. Strategy for insect pest control in cocoa. Am.J. Exp. Agric. 6(6): 416-423.
Akrofi AY. 2015. Phytophthora megakarya: a review on its status as a pathogen on cacao in West Africa. Afr. Crop Sci. J. 23(1): 67-87.

Anita-Sari I \& Susilo AW. 2013. Stabilitas karakter pembungaan, pertunasan, dan potensi jumlah buah pada 21 klon kakao harapan koleksi Puslitkoka. Pelita Perkebunan. 29(2): 82-92.

Anita-Sari I \& Susilo AW. 2015. Phenology of flowering and pod maturity on some cocoa (Theobroma cacao L.) clones. Pelita Perkebunan. 31(2): 7380 .

Danial D, Fiana Y, Handayani F, \& Hidayanto M. 2015. Peningkatan produksi dan mutu kakao melalui kegiatan Gernas di Kalimantan Timur. Dalam: Setyawan AD, Sugiyarto, Pitoyo A, Hernawan UE, Sutomo, Widiastuti A, \& Raqib SM (Eds.). Prosiding Seminar Nasional Masyarakat Biodiversitas Indonesia. 1(5): 1203-1210. Masyarakat Biodiversitas Indonesia. Surakarta. Agustus 2015.

Dinarti D, Susilo AW, Meinhardt LW, Ji K, Motilal LA, Mischke S, \& Zhang D. 2015. Genetic diversity and parentage in farmer selections of cacao from Southern Sulawesi, Indonesia revealed by microsatellite markers. Breeding Sci. 65(5): 438446.

Deberdt P, Mfegue CV, Tondje PR, Bon MC,Ducamp M, Hurard C, Begoude BAD, Ndoumbe-Nkeng M, Hebbar PK, \& Cilas C. 2008. Impact of environmental factors, chemical fungicide and biological control on cacao pod production dynamics and black pod disease (Phytophthora megakarya) in Cameroon. Biol. Control. 44(2): 149-159.

Directorate General of Estate Crops. 2016. Tree Crop Estate Statistics of Indonesia. 2015-2017 Cocoa. Ministry of Agriculture. Jakarta.

Efombagn MIB, Marelli JP, Ducamp M, Cilas C, Nyasse S, \& Vefonge D. 2004. Effect of fruiting traits on the field resistance of cocoa (Theobroma cacao L.) clones to Phytophthora megakarya. J. Phytopathology. 152(10): 557-562.

Evizal R, Sumaryo, Sa'diyah N, Prasetyo J, Prasmatiwi FE, \& Nurmayasari I. 2016. Farm performance and problem area of cocoa plantation in Lampung Province, Indonesia. In: Wulandari C, Rini MV, Kaskoyo H, Saputra H, Riani WH, Aristoteles, 
\& Pamungkas A (Eds.). Proceeding the USR International Seminar on Food Security. pp. 193-205. University of Lampung. Bandar Lampung. August 23-25, 2016.

Evizal R, Prasmatiwi FE, Pasaribu MC, Ivayani, Wibowo L, Rahmawati W, \& Karyanto A. 2018. Competitive and sustainable production of cocoa in Tanggamus, Lampung Province, Indonesia. In: Haryanto A, Triyono S, Waluyo S, Asmara S, Suhandy D, Telaumbanua M, Sugianti C, Rahmawati W, \& Saputra TW (Eds.). Proceeding of ISAE Lampung International Seminar. pp. 705-712. University of Lampung. Bandar Lampung. August 10-12, 2017.

Guest D. 2007. Black pod: Diverse pathogens with a global impact on cocoa yield. Phytopathology. 97(12): 1650-1653.

Hoopen GMT, Deberdt P, Mbenoun M, \& Cilas C. 2012. Modelling cacao pod growth: implications for disease control. Ann. Appl. Biol. 160(3): 260272.

Iwaro AD, Butler DR, \& Eskes AB. 2006. Sources of resistance to Phytophthora pod rot at the International Cocoa Genebank, Trinidad. Genet. Resour. Crop Evol. 53(1): 99-109.

McMahon P \& Purwantara A. 2004. Phytophthora on cocoa. In: Drenth A \& Guest DI (Eds). Diversity and Management of Phytophthora in Southeast Asia. pp. 104-115. ACIAR. Monograph Melbourne.

McMahon P, Purung H, Lambert S, Mulia S, Nurlaila, Susilo AW, Sulistyowati E, Sukamto S, Israel M, Saftar A, Amir A, Purwantara A, Iswanto A, Guest D, \& Keane P. 2015. Testing local cocoa selections in three provinces in Sulawesi: (i) Productivity and resistance to cocoa pod borer and Phytophthora pod rot (black pod). Crop Prot. 70: $28-39$.

Melnick RL, Strem MD, Crozier J, Sicher RC, \& Bailey BA. 2013. Physiological and molecular. Plant Pathology. 84:153-162.

Motamayor JC, Lachenaud P, Mota JWS, Loor R, Kuhn DN, Brown JS, \& Schnell RJ. 2008. Geographic and genetic population differentiation of the Amazonian chocolate tree (Theobroma cacao L). PloS ONE. 3(10): e3311.
Niemenak N, Cilas C, Rohsius C, Bleiholder H, Meier U, \& Lieberei R. 2010. Phenological growth stages of cacao plants (Theobroma sp.): codification and description according to the BBHC scale. Ann. Appl. Biol. 156(1): 13-24.

Prawoto AA. 2014. Dinamika pertunasan, layu pentil, dan ketepatan taksasi produksi beberapa klon kakao. Pelita Perkebunan. 30(2): 100-114.

Rubiyo \& Siswanto. 2012. Peningkatan produksi dan pengembangan kakao (Theobroma cocoa L.) di Indonesia. Buletin Ristri. 3(1): 33-48.

Rubiyo \& Amaria W. 2013. Ketahanan tanaman kakao terhadap penyakit busuk buah (Phytophthora palmivora Butl.). Perspektif. 12(1): 23-26.

Saidah, Negara A, \& Sahadi. 2015. Kajian adaptasi beberapa klon sebagai bahan sambung samping kakao di Sulawesi Tengah. Dalam: Setyawan AD, Sugiyarto, Pitoyo A, Hernawan UE, Sutomo, Widiastuti A, \& Raqib SM (Eds.). Prosiding Seminar Nasional Masyarakat Biodiversitas Indonesia. Surakarta. Oktober 2015. Nas. Masy. Biodiv. Indon. 1(7): 1661-1665.

Susilo AW, Anita-Sari I, \& Imran. 2015. Yield performance of locally selected cocoa clones in North Luwu. Pelita Perkebunan. 31(3): 152162.

Thevenin JM, Rossi V, Ducamp M, Doare F, Condina V, \& Lachenaud P. 2012. Numerous clones resistant to Phytophthora palmivora in the Guiana genetic group of Theobroma cacao L. PloS ONE. 7(7): e40915.

Vanegtern B, Rogers M, \& Nelson S. 2015. Black Pod Rot of Cacao Caused by Phytophthora palmivora. Plant Disease Department. University of Hawaii.

Zhang D \& Mutilal L. 2016. Origin, dispersal, and current global distribution of cacao genetic diversity. In: Bailey BA \& Meinhardt LW (Eds.). Cacao Disease.pp. 1-31. Springer. Switzerland. 